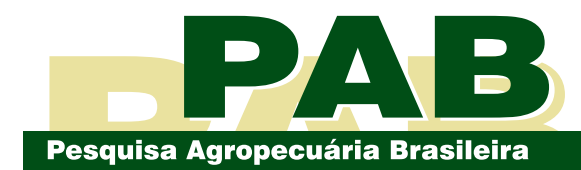

ISSN 1678-3921

Journal homepage: www.embrapa.br/pab

For manuscript submission and journal contents, access: www.scielo.br/pab

Thematic Issue - Regional Agrominerals/ Original Article

\title{
Ammonia volatilization and agronomical efficiency of a mixture of urea with natural zeolite for rose fertilization
}

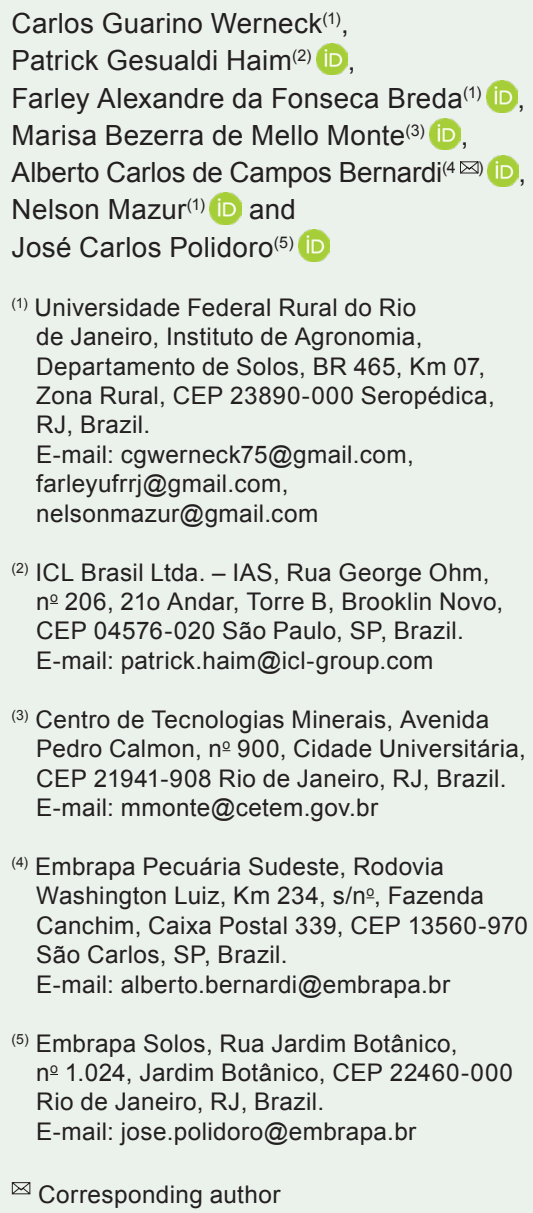

(4) Embrapa Pecuária Sudeste, Rodovia Washington Luiz, Km 234, s/no, Fazenda Canchim, Caixa Postal 339, CEP 13560-970 São Carlos, SP, Brazil.

E-mail: alberto.bernardi@embrapa.br

(5) Embrapa Solos, Rua Jardim Botânico, no 1.024, Jardim Botânico, CEP 22460-000 Rio de Janeiro, RJ, Brazil. E-mail: jose.polidoro@embrapa.br

$凶$ Corresponding author

Received

April 29, 2019

Accepted

November 19, 2021

How to cite

WERNECK, C.G.; HAIM, P.G.; BREDA, F.A da F.; MONTE, M.B. de M.; BERNARDI, A.C. de C.; MAZUR, N.; POLIDORO, J.C. Ammonia volatilization and agronomical efficiency of a mixture of urea with natural zeolite for rose fertilization. Pesquisa Agropecuária Brasileira, v.56, e01449, 2021. DOI: https://doi. org/10.1590/S1678-3921.pab2021.v56.01449.

\begin{abstract}
The objective of this work was to evaluate the losses of $\mathrm{N}-\mathrm{NH}_{3}$ by volatilization and the agronomic efficiency of a mixture of urea with natural zeolite, as topdressing fertilization, in an area for the commercial production of roses (Rosa spp.). The treatments were: two rates of urea $\left(60\right.$ and $\left.120 \mathrm{~kg} \mathrm{ha}^{-1}\right)$, with and without zeolite. The $\mathrm{N}$ sources were applied directly to soil surface, and volatilization was determined using a free semi-open static chamber. The quantitative and qualitative variables of the collected flower stems were used to determine the agronomical efficiency of the fertilizers. The zeolite mixture reduces ${\mathrm{N}-\mathrm{NH}_{3}}_{3}$ losses in $30 \%$, compared with the commercial urea fertilizer, and shows a higher agronomic efficiency, resulting in an increase of 25 dozen of flower stems per each kilogram of $\mathrm{N}$ applied.
\end{abstract}

Index terms: Rosa, aluminosilicates, ammonium trapping, slow release, stilbite.

\section{Volatilização de amônia e eficiência agronômica de mistura de ureia com zeólita natural para fertilização de rosas}

Resumo - O objetivo deste trabalho foi avaliar as perdas de $\mathrm{N}^{-\mathrm{NH}_{3}}$ por volatilização e a eficiência agronômica de mistura de ureia com zeólita natural, como adubação de cobertura, em área de produção comercial de rosas (Rosa spp.). Os tratamentos foram: duas doses de ureia (60 e $\left.120 \mathrm{~kg} \mathrm{ha}^{-1}\right)$, com e sem zeólitas. As fontes nitrogenadas foram aplicadas na superfície do solo, e a volatilização foi determinada com uso de câmara semiaberta livre estática. As variáveis quantitativas e qualitativas das hastes florais colhidas foram utilizadas para determinação da eficiência agronômica dos fertilizantes. A mistura com zeólitas diminuiu as perdas de $\mathrm{N}^{-\mathrm{NH}_{3}}$ em $30 \%$, em comparação ao fertilizante ureia comercial, e mostra maior eficiência agronômica, tendo resultado em incremento de 25 dúzias de hastes florais por quilograma de $\mathrm{N}$ aplicado.

Termos para indexação: Rosa, alumino-silicatos, captura de amônio, liberação lenta, estilbita.

\section{Introduction}

Urea (44 to $46 \% \mathrm{~N}$ ) is the most used $\mathrm{N}$ fertilizer in world agriculture and in Brazil, representing, respectively, 50 and $60 \%$ of total $\mathrm{N}$ fertilizer consumption (IFA, 2018). However, its application to the soil is usually characterized by high $\mathrm{N}-\mathrm{NH}_{3}$ losses due to volatilization, which may be 
up to approximately $64 \%$ of the $\mathrm{N}$ applied (Pan et al., 2016). The low use efficiency of the $\mathrm{N}$ fertilizer by the cultivated plants supports this result, since only 30 to $60 \%$ of the $\mathrm{N}$ fertilizer applied to the soil are taken up (Timilsena et al., 2015).

Therefore, to be considered adequate, the $\mathrm{N}$ fertilizer needs to reach a high agronomic efficiency. For this, it must reduce $\mathrm{N}-\mathrm{NH}_{3}$ losses by volatilization and maximize the extraction of $\mathrm{N}$ fertilizer by plants (Timilsena et al., 2015; Pan et al., 2016). The agronomic efficiency of a fertilizer (AEF) correlates the agricultural yields obtained with and without the application of fertilizers and expresses the increment in the economic output provided per unit of $\mathrm{N}$ fertilizer applied to the soil (Dobermann, 2007). Furthermore, a fertilizer is only considered commercially viable if the increment it provides is greater than that of the conventionally used urea fertilizer (Timilsena et al., 2015; Pan et al., 2016). In this scenario, the technological development of fertilizers with a low and controlled $\mathrm{N}$ release becomes crucial to the economic and environmental sustainability of modern agriculture.

A promising alternative for the industries of fertilizers is the use of natural zeolites to develop $\mathrm{N}$ fertilizers based on urea- $\mathrm{N}$. Zeolites constitute a group with more than 80 types of known and naturally occurring minerals, which present a high adsorption ability and cation exchange capacity (Ramesh \& Reddy, 2011; Latifah et al., 2017), resulting in a significant potential of interaction with exchangeable cations (such as $\mathrm{NH}_{4}^{+}, \mathrm{K}^{+}, \mathrm{Ca}^{+2}$, and $\mathrm{Mg}^{+2}$ ) and volatile gases (including $\mathrm{NH}_{3}$ and $\mathrm{CH}_{4}$ ), which are conducted to the atmosphere by water vapor ascending from the soil (Fergunson \& Pepper, 1987; Werneck et al., 2012; Bernardi et al., 2016; Pan et al., 2016). Zeolites can be used in agriculture due to their potential of interaction with $\mathrm{N}$ compounds, and their capacity of storing and slowly releasing this nutrient can lead to a significant economy in fertilizer use and, consequently, to environmental protection (Bernardi et al., 2013b).

Studies have shown that the addition of zeolites to urea increases $\mathrm{N}$ use efficiency, reduces $\mathrm{N}-\mathrm{NH}_{3}$ losses by volatilization (Bernardi et al., 2011, 2013a, 2013b; Ramesh \& Reddy, 2011; Werneck et al., 2012; Campana et al., 2015; Pan et al., 2016), and increases the dry mass yield of crops (Bernardi et al., 2011, 2013a). The principle of action of zeolite in $\mathrm{NH}_{3}$ conservation is the reduction in the concentration of this compound in the soil solution, by retaining the negative charges of the mineral, as well as the interference in the nitrification process (Fergunson \& Pepper, 1987; Bernardi et al., 2011, 2013a; Ramesh \& Reddy, 2011; Latifah et al., 2017). These results evidence the potential of the use of zeolite minerals in the technological development of $\mathrm{N}$ fertilizers with a slow and controlled release.

Agricultural systems, such as floriculture, in which the achievement of high yields depends on a high $\mathrm{N}$ supply, can benefit from that technology. According to Instituto Brasileiro de Floricultura (Ibraflor, 2021), the flower and ornamental plant market moved around $\mathrm{R} \$ 8.5$ billion in 2019 and has been increasing annually from 8 to $10 \%$ in Brazil, where cut roses (Rose spp.) are the main product of this market segment. Although concentrated in the state of São Paulo, the production and market of this flower and of ornamental plants occur throughout Brazil (Neves \& Pinto, 2015). The state of Rio de Janeiro is the second greatest market, in which the region of Nova Friburgo stands out in the production of cut flowers, especially roses (Reis \& Marafon, 2020).

The nutrients most required by roses are $\mathrm{N}$ and $\mathrm{K}$ (Villas Bôas et al., 2008). Most of the $\mathrm{N}$ is absorbed by the rose bush at the vegetative stage when the plant develops a larger leaf area and accumulates supplies that will be used in the formation of its basal branches (Villas Bôas et al., 2008). The extraction of $\mathrm{N}$ depends on plant variety and size and can vary from 158 to $392 \mathrm{~kg} \mathrm{ha}^{-1} \mathrm{~N}$ (Villas Bôas et al., 2008). In the system of flower production in Nova Friburgo, the common practice is applying eight to ten annual $\mathrm{N}$ fertilizations using 100 to $120 \mathrm{~kg} \mathrm{ha}^{-1} \mathrm{~N}$, which represents an input of approximately $1,000 \mathrm{~kg} \mathrm{ha}^{-1} \mathrm{~N}$ per year (Villas Bôas et al., 2008; Reis \& Marafon, 2020). Considering the agronomic recommendation of $60 \mathrm{~kg} \mathrm{ha}^{-1} \mathrm{~N}$ per month during the productive cycle of the crop, which occurs between August and June (Ribeiro et al., 1999), the annual $\mathrm{N}$ input should not exceed $600 \mathrm{~kg} \mathrm{ha}^{-1} \mathrm{~N}$. However, the low efficiency of urea-N use by cultivated plants makes it impossible to extract the $\mathrm{N}$ necessary for high yields - estimated to be $500 \mathrm{~kg} \mathrm{ha}^{-1} \mathrm{~N}$ per year (Barbosa, 2003) - using the recommended rate. These findings explain the use of $\mathrm{N}$ rates up to $100 \%$ higher than the one recommended and reinforce the low agronomic efficiency of the urea fertilizer. 
The objective of this work was to evaluate the losses of $\mathrm{N}-\mathrm{NH}_{3}$ by volatilization and the agronomic efficiency of a mixture of urea with natural zeolite, as topdressing fertilization, in an area for the commercial production of roses (Rosa spp.).

\section{Materials and Methods}

The experiment was carried out in a commercial rose (Rosa spp.) crop cultivated in the São João farm, located in the district of Nova Friburgo, in the state of Rio de Janeiro, Brazil $\left(22^{\circ} 18^{\prime} 50^{\prime \prime} \mathrm{S}, 42^{\circ} 27^{\prime} 33^{\prime \prime} \mathrm{W}\right.$, at $966 \mathrm{~m}$ of altitude). The soil of the area was classified as a Argissolo Amarelo (Calderano Filho et al., 2003), i.e., an Ultisol, which presented the following chemical characteristics: $\mathrm{pH} \mathrm{H}_{2} \mathrm{O}$ 5.4; 0.0, 10.0, 2.8, 7.0, 15.3, and $22.3 \mathrm{cmol}_{\mathrm{c}} \mathrm{dm}^{-3} \mathrm{Al}, \mathrm{Ca}, \mathrm{Mg}, \mathrm{H}+\mathrm{Al}, \mathrm{S}$, and effective cation exchange capacity, respectively; 80.0, 1,073.0, and $1,946.4 \mathrm{mg} \mathrm{dm}^{-3} \mathrm{Na}, \mathrm{K}$, and $\mathrm{P}$, respectively; base saturation of $68.5 \%$; and 3.8 and $54.0 \mathrm{~g} \mathrm{~kg}^{-1} \mathrm{~N}$ and organic matter, respectively.

The treatments followed a $2 \times 2+1$ factorial arrangement, with the following factors: two rates (60 and $120 \mathrm{~kg} \mathrm{ha}^{-1} \mathrm{~N}$ ) of urea fertilizer, absence or presence of zeolite, and an additional treatment without $\mathrm{N}$ application (control), resulting in five treatments. The experimental design was randomized complete blocks, with three replicates, and the experimental units were composed of four linear meters (17 plants), covering $4.5 \mathrm{~m}^{2}$ of the experimental area.

The zeolite mixture was obtained by a physical process in which urea fertilizer and zeolite were mixed; the amount of zeolite present in the mixture corresponded to $20 \%(\mathrm{p} / \mathrm{p})$ of the fertilizer rates adopted in the treatments. The urea fertilizer used had an approximate diameter of 2.0 to $3.0 \mathrm{~mm}$. The natural zeolite was collected in the sedimentary basin Bacia do Parnaíba (Rezende \& Angelica, 1999) and then processed and characterized as described by Monte et al. (2009). Zeolite cation exchange capacity was $169 \mathrm{cmol}_{\mathrm{c}} \mathrm{dm}^{-3}$, whose ideal formula should be $(\mathrm{Na}, \mathrm{K})$ $\mathrm{Ca}_{2}\left[\mathrm{Al}_{5} \mathrm{Si}_{13} \mathrm{O}_{36}\right] \cdot 14 \mathrm{H}_{2} \mathrm{O}$ ), with an average composition of $64.7,12.7,0.8,0.97,3.1,1.15,3.3,0.12,0.6,0.12 \%$ $\mathrm{SiO}_{2}, \mathrm{Al}_{2} \mathrm{O}_{3}, \mathrm{BaO}, \mathrm{Na}_{2} \mathrm{O}, \mathrm{K}_{2} \mathrm{O}, \mathrm{CaO}, \mathrm{MgO}, \mathrm{Fe}_{2} \mathrm{O}_{3}, \mathrm{P}_{2} \mathrm{O}_{5}$, and $\mathrm{TiO}_{2}$, respectively, and a particle diameter size smaller than $4.67 \mathrm{~mm}$ (Monte et al., 2009).

Nitrogen topdressing fertilization was applied to the rose crop on April 14 and June 8 (fertilizations
$\mathrm{C} 1$ and $\mathrm{C} 2$, respectively), using the rates of 120 and $60 \mathrm{~kg} \mathrm{ha}^{-1} \mathrm{~N}$, respectively, that are commonly practiced in the region and recommended in the literature (Ribeiro et al., 1999).

$\mathrm{N}-\mathrm{NH}_{3}$ losses by volatilization were evaluated using a free and static semi-open chamber manufactured with a PET plastic bottle, as described by Araújo et al. (2009). The $\mathrm{N}^{-\mathrm{NH}_{3}}$ collector system was made with a $2.0 \mathrm{~L}, 0.10 \mathrm{~m}$ diameter, and bottomless transparent plastic recipient, within which a $50 \mathrm{~mL}$ flask was fixed, containing $10 \mathrm{~m}$ of $\mathrm{H}_{2} \mathrm{SO}_{4} 1.0 \mathrm{~mol}+2.0 \%$ glycerin $(\mathrm{v} / \mathrm{v})$ solution. A polyurethane foam layer - with 0.003 $\mathrm{m}$ thickness, $0.25 \mathrm{~m}$ width, and $0.25 \mathrm{~m}$ length - was added to capture volatilized $\mathrm{N}-\mathrm{NH}_{3}$ in each chamber (Araújo et al., 2009). Two chambers were used per plot, totaling six replicates per treatment. The collection of strips for capturing the volatilized $\mathrm{NH}_{3}$ started two days before and followed at 24-hour intervals for six consecutive days after the $\mathrm{N}$ sources were applied. For the analysis of the collected $\mathrm{NH}_{3}$, the foam, together with the acidic solution remaining in the $50 \mathrm{~mL}$ flask, was transferred to a $250 \mathrm{~mL}$ conical flask, to which $50 \mathrm{~mL}$ distilled water were added; after stirring at 250 $\mathrm{RPM}$, for $15 \mathrm{~min}$, a $5.0 \mathrm{~mL}$ aliquot was digested with sulfuric acid, distilled by the Kjeldahl method, and titrated with $0.015 \mathrm{~N}$ sulfuric acid (Araújo et al., 2009).

The floral stems produced were integral and continually harvested between April 16 and May 7 in $\mathrm{C} 1$ and between July 10 and August 25 in C2. The total fresh mass yield was determined, as well as the total harvested stems, which were divided into short, medium, and long. The floral stems were split into two parts - stems and buds -, which were dried with forced-air circulation, at $65^{\circ} \mathrm{C}$, for 72 hours, in order to determine the total dry mass yield of each one. The samples were ground in a 20 -mesh sieve, and total $\mathrm{N}$ contents were obtained according to Carmo et al. (2000), by determining individually the extraction of $\mathrm{N}$ by each stem part and then summing them up to obtain the total $\mathrm{N}$ extracted by the harvested commercial stems.

The AEF applied was determined using the equation suggested by Dobermann (2007): $A E F=\left(Y_{F}-Y_{0}\right) /\left(A_{N}\right)$ where AEF is the agronomic efficiency of the fertilizer; $Y_{F}$ is the yield of the treatment with the use of the fertilizer; $\mathrm{Y}_{0}$ is the yield of the control treatment (without the use of $\mathrm{N}$ fertilizer); and $\mathrm{A}_{\mathrm{N}}$ is the amount of nutrient applied. 
The AEF was determined for the following variables: short, medium, long, and total stems (units produced per kilogram of $\mathrm{N}$ applied); fresh and dry matter yields (kilogram produced per kilogram of $\mathrm{N}$ used); and $\mathrm{N}$ extraction (gram of $\mathrm{N}$ extracted per kilogram of $\mathrm{N}$ used).

The data analysis was performed using resources of the SAEG, version 9.1, system for statistical analysis (Universidade Federal de Viçosa, Viçosa, MG, Brazil), and data were assessed for normality of errors and homogeneity of variances using Lilliefors' and Cochran-Bartlett's tests, respectively. The analysis of variance was performed, and, when there were significant differences, Scott-Knott's test was applied for $\mathrm{N}_{-} \mathrm{NH}_{3}$ volatilization and Student's t-test for qualitative and quantitative variables and the AEF.

\section{Results and Discussion}

The $\mathrm{N}-\mathrm{NH}_{3}$ losses that occurred in $\mathrm{Cl}$ showed a significant effect $(\mathrm{p}<0.01)$ of the zeolite and urea mixture at the highest $\mathrm{N}$ rate, with a reduction in volatilization up to the third day after fertilization. On the fourth day, there was a significant effect $(p<0.05)$ only of the application of $120 \mathrm{~kg} \mathrm{ha}^{-1}$, when the losses were of 2.87 and $1.62 \mathrm{~g} \mathrm{~m}^{-2} \mathrm{~N}$ per day with single urea and with the mixture between zeolite and urea, respectively. These values represent a $43 \%$ reduction in losses due to the effect of zeolite. On the fourth and fifth days, from 48 to 72 hours after fertilization, the effect of zeolite on loss reduction was significant $(\mathrm{p}<0.01)$ regardless of the applied $\mathrm{N}$ rate. For single urea and the zeolite mixture, respectively, losses were of 1.12 and $0.79 \mathrm{~g} \mathrm{~m}^{-2} \mathrm{~N}$ per day and of 0.68 and 0.36 $\mathrm{g} \mathrm{m}^{-2} \mathrm{~N}$ per day, when using the highest and lowest rates. In addition, the reduction of $\mathrm{N}-\mathrm{NH}_{3}$ losses due to the effect of the used mixture was approximately of 30 and $46 \%$ with the applications of the highest and lowest $\mathrm{N}$ rates, respectively.

In $\mathrm{C} 2$ (Figure $1 \mathrm{~B}$ ), the application of the lowest rate of the mixture did not have a significant effect on losses due to volatilization ( $\mathrm{p}>0.05)$ during the entire experimental period. In this case, the losses were equivalently low and started on the third day after fertilization, reaching a peak on the fifth day, with values of approximately $0.3 \mathrm{~g} \mathrm{~m}^{-2} \mathrm{~N}$ per day, and then decreasing until the eighth day.

Between the first and second days after $\mathrm{C} 2$, significant losses of $0.29 \mathrm{~g} \mathrm{~m}^{-2}$ per day due to volatilization were observed with the mixture of $60 \mathrm{~kg} \mathrm{ha}^{-1} \mathrm{~N}$ and zeolite. However, this value was lower than that of $0.66 \mathrm{~g} \mathrm{~m}^{-2}$ per day obtained with the application of only the lowest fertilizer rate. This indicates the positive effect of zeolite stilbite, which reduced $56 \%$ of the losses in that period. On the fifth day of evaluation, i.e., between 48 and 72 hours after fertilization, there was a peak in losses of 1.3 and 0.75 $\mathrm{g} \mathrm{m}^{-2}$ per day for $120 \mathrm{~kg} \mathrm{ha}^{-1} \mathrm{~N}$ without and with zeolite, respectively, followed by a decrease until the end of the experimental period (Figure $1 \mathrm{~B}$ ). Therefore, zeolite reduced approximately $42 \%$ of the losses (Figure $1 \mathrm{~B}$ ). On the sixth and seventh days, that is, 72 to 120 hours
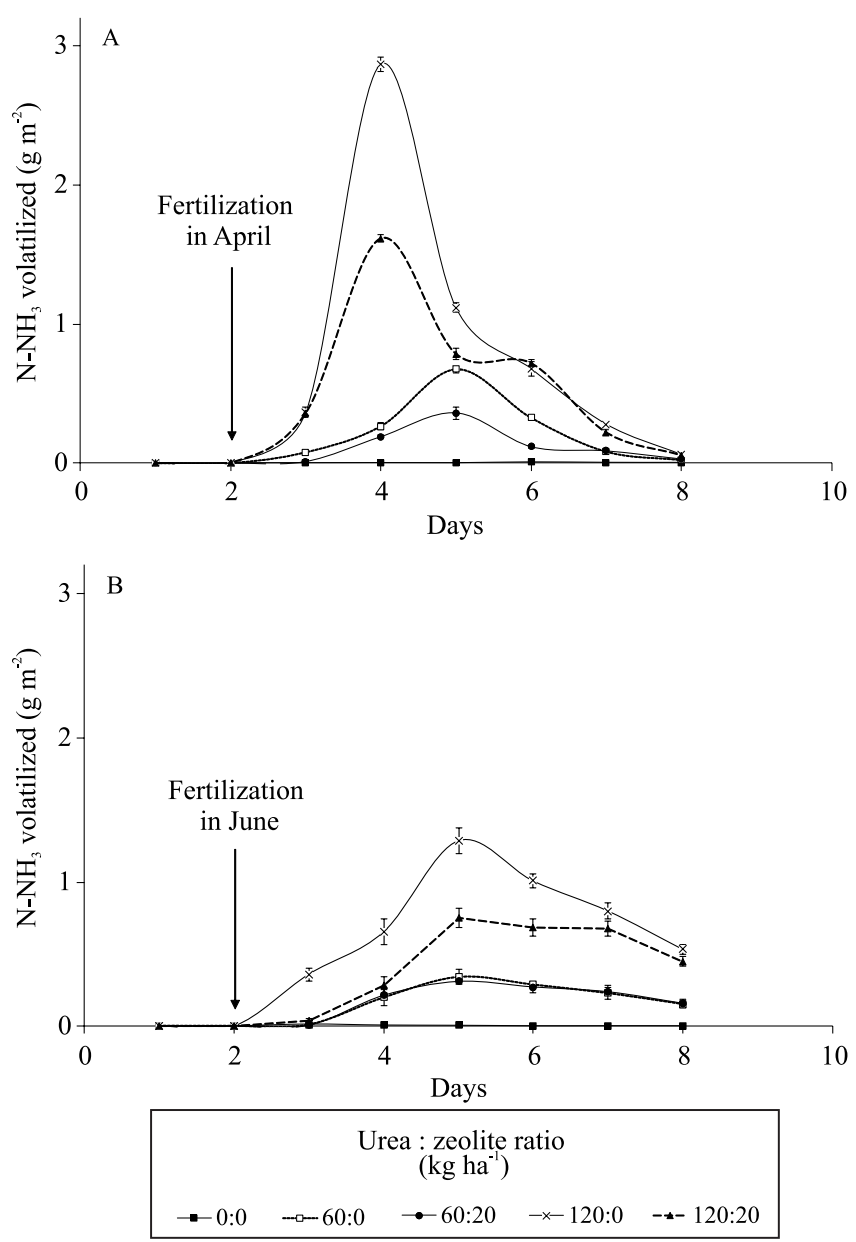

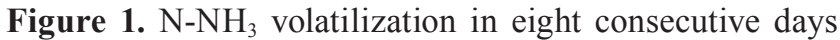
due to $\mathrm{N}$ topdressing fertilizations with urea, at the rates of 60 and $120 \mathrm{~kg} \mathrm{ha}^{-1} \mathrm{~N}$, with or without the addition of zeolite $(20 \% \mathrm{p} / \mathrm{p})$, applied to the rose (Rosa spp.) crop in April C1 (A) and June - C2 (B). Vertical bars represent the mean standard error. 
after fertilization, a significant effect $(\mathrm{p}<0.01)$ of zeolite on the reduction of volatilization was observed. A total of 1.0 and $0.68 \mathrm{~g} \mathrm{~m}^{-2}$ per day and of 0.8 and $0.68 \mathrm{~g} \mathrm{~m}^{-2} \mathrm{~N}$ per day was volatilized on the sixth and seventh days, respectively, due to the applications of $120 \mathrm{~kg} \mathrm{ha}^{-1} \mathrm{~N}$ without and with zeolite. These results represent a significant effect of the mineral in reducing, in approximately 33 and $15 \%$, the losses that occurred on the sixth and seventh days, respectively.

Zeolite showed significant effects $(\mathrm{p}<0.01)$ as a topdressing fertilizer in $\mathrm{C} 1$ and $\mathrm{C} 2$, with $\mathrm{N}-\mathrm{NH}_{3}$ losses generally occurring within 120 hours after treatment application (Figure 1 A and B). As the urea applied to the soil is typically hydrolyzed in two or three days (Pan et al., 2016), the most significant losses of $\mathrm{N}-\mathrm{NH}_{3}$ were observed in this period (Araújo et al., 2009; Bernardi et al., 2013b; Campana et al., 2015). These results are indicative that the effects of zeolite occurred in the scenarios with the most significant potential for volatilization losses, confirming the mineral's ability of adsorbing $\mathrm{NH}_{4}^{+}$. Other authors highlight the possibility of using zeolites in mixtures with nitrogenous mineral fertilizers (Fergunson \& Pepper, 1987; Ramesh \& Reddy, 2011; Bernardi et al., 2011, 2013b; Latifah et al., 2017), aiming at the technological development of zeolitic fertilizers with a potential to reduce volatilization losses during planting and topdressing fertilization.

Regardless of the $\mathrm{N}$ rate applied, the zeolite mixture had a reducing effect $(\mathrm{p}<0.01)$ on total $\mathrm{N}-\mathrm{NH}_{3}$ losses in $\mathrm{C} 1$ and $\mathrm{C} 2$. In $\mathrm{C} 1$, the lowest $\mathrm{N}$ rate resulted in losses of 1.46 and $0.81 \mathrm{~g} \mathrm{~m}^{-2} \mathrm{~N}$, respectively, with the application of single urea and the zeolite mixture, representing 24.3 and $13.5 \%$ of the $\mathrm{N}$ applied to the soil. Therefore, the zeolite mixture reduced $\mathrm{N}-\mathrm{NH}_{3}$ losses in approximately $45 \%$ (Figure $2 \mathrm{~A}$ ). At the highest $\mathrm{N}$ rate, the urea and zeolite mixture caused losses of 5.38 and $3.76 \mathrm{~g} \mathrm{~m}^{-2} \mathrm{~N}$, respectively, representing 44.8 and $31.3 \%$ of the $\mathrm{N}$ applied to the soil, and the mixture was responsible for a reduction of $30 \%$ in losses. The percentage of $\mathrm{N}$ loss in all treatments was lower than those reported in field conditions, where urea was applied to soil surface, without being incorporated into the soil (Pan et al., 2016; Latifah et al., 2017).

The effect of the urea and zeolite mixture was observed $(p<0.01)$ only with the application of the highest $\mathrm{N}$ rate in $\mathrm{C} 2$ (Figure $2 \mathrm{~B}$ ). When the lowest $\mathrm{N}$ rate was applied, the total $\mathrm{N}-\mathrm{NH}_{3}$ losses accumulated by the mixture were equivalent $(\mathrm{p}>0.05)$ and represented approximately $20 \%$ of the $\mathrm{N}$ applied.

The average atmospheric temperatures recorded in $\mathrm{C} 2$ varied from 16 to $19^{\circ} \mathrm{C}$ and reduced the potential of $\mathrm{N}^{-\mathrm{NH}_{3}}$ losses in the soil, when compared with the average temperatures between 20 and $22^{\circ} \mathrm{C}$ in $\mathrm{C} 1$. Temperature affects $\mathrm{N}-\mathrm{NH}_{3}$ losses due to its influence on the activity of the enzyme urease, and the urea hydrolysis rate increases when temperature rises to $40^{\circ} \mathrm{C}$ (Baptista-Filho et al., 2008; Pan et al., 2016). Variations in $\mathrm{N}-\mathrm{NH}_{3}$, therefore, might occur depending on temperature and the applied rates. When the urea and zeolite mixture was applied at the rates of 60 and $120 \mathrm{~kg} \mathrm{ha}^{-1} \mathrm{~N}$, for example, total accumulated $\mathrm{N}-\mathrm{NH}_{3}$ losses were of 4.65 and $2.89 \mathrm{~g} \mathrm{~m}^{-2} \mathrm{~N}$, respectively, representing 38.8 and $24.1 \%$ of the $\mathrm{N}$ provided to the soil (Figure $1 \mathrm{~B}$ ). These results are indicative of a reduction of approximately $38 \%$ in $\mathrm{N}^{-\mathrm{NH}_{3}}$ losses due
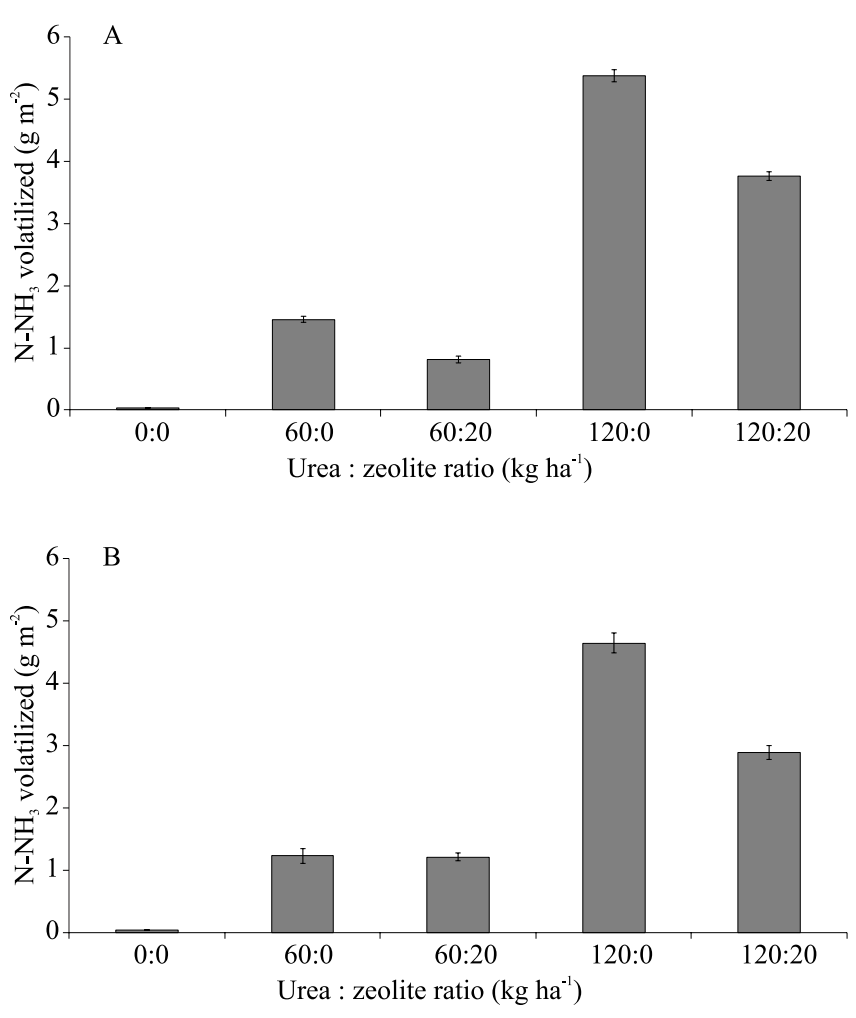

Figure 2. Total of $\mathrm{N}-\mathrm{NH}_{3}$ volatilized in eight consecutive days about the nitrogen topdressing fertilization with urea and zeolite mixture, at the doses of 60 and $120 \mathrm{~kg} \mathrm{ha}^{-1} \mathrm{~N}$, performed in the rose bush (Rosa spp.) crop in April - C1 (A) and June - C2 (B). Vertical bars represent the mean standard error. 
to the effect of the used mixture. Moreover, the lowest rate of the urea and zeolite mixture caused a reduction of $45 \%$ in $\mathrm{N}^{-\mathrm{NH}_{3}}$ losses. Campana et al. (2015), when using the combination of urea with zeolites, also found differences in losses by volatilization, which were higher in summer than in winter.

The significant reductions in $\mathrm{N}-\mathrm{NH}_{3}$ losses can be explained by the action of zeolite in the preservation of $\mathrm{NH}_{4}{ }^{+}$, by decreasing the concentration of this ion in the soil solution through cation exchange, which favors the formation of $\mathrm{NH}_{4}^{+}$rather than $\mathrm{NH}_{3}$ volatilization into the atmosphere (Fergunson \& Pepper, 1987; Bernardi et al., 2011, 2013b; Latifah et al., 2017). In addition, zeolites also have potential to adsorb $\mathrm{NH}_{3}$ in an aqueous solution (Fergunson \& Pepper, 1987), as long as this form of $\mathrm{N}$ is found in the soil solution. Under controlled conditions, the zeolite concentrate obtained from the zeolite used in the present study was highly efficient in confining $\mathrm{N}$ in its structure, inhibiting the release of $\mathrm{NH}_{3}$ to the air even at temperatures higher than $45^{\circ} \mathrm{C}$ (Baptista-Filho et al., 2008).

Rose bush yield was significantly affected by the fertilizer when the reduction in $\mathrm{N}^{-} \mathrm{NH}_{3}$ losses by volatilization increased $(p<0.05)$ the AEF for floral stem yield, confirming the observations of Barbosa (2003) and Villas Bôas et al. (2008). For the variables short, long, and total stems, as well as fresh and dry matter yield and $\mathrm{N}$ extraction, the AEF was higher $(p<0.05)$ in the treatments with 60 and $120 \mathrm{~kg} \mathrm{ha}^{-1} \mathrm{~N}$ with zeolite in $\mathrm{Cl}$ and with $60 \mathrm{~kg} \mathrm{ha}^{-1} \mathrm{~N}$ with zeolite in C2 (Table 1).

In $\mathrm{Cl}$, the AEF for stem yield at both rates of the zeolite mixture differed from that of the control $(p<0.05)$, with increments of 17.5 and 40 dozen of total stems per kilogram of $\mathrm{N}$ applied (Table 1). It was also observed that 120 and $60 \mathrm{~kg} \mathrm{ha}^{-1} \mathrm{~N}$ with zeolite increased $(p<0.05)$ the economic output of total stems in 22 and 39 dozen per kilogram of $\mathrm{N}$ applied, respectively, when compared with the outputs obtained with the same rates but without the mineral.

In the case of the mixture between $60 \mathrm{~kg} \mathrm{ha}^{-1} \mathrm{~N}$ and zeolite, $26.66 \mathrm{~kg}$ of the mineral were used, since $60 \mathrm{~kg}$ $\mathrm{N}$ corresponds to the rate of $133.33 \mathrm{~kg}$ commercial urea $(45 \% \mathrm{~N})$ and the proportion of zeolite is $20 \%(\mathrm{p} / \mathrm{p})$ in relation to urea. In $\mathrm{C}$, each unit $(\mathrm{kg})$ of zeolite at the rate of $60 \mathrm{~kg} \mathrm{ha}^{-1} \mathrm{~N}$ provided an increment of 87.8 dozen stems per hectare, considering the increment of 39 dozen stems per kilogram of $\mathrm{N}$ applied, when compared with that of $60 \mathrm{~kg} \mathrm{ha}^{-1} \mathrm{~N}$ alone, which corresponds to 2,340 dozens of stems per $60 \mathrm{~kg}$ of $\mathrm{N}$ applied.

In $\mathrm{C} 2$, only the lowest rate of the urea and zeolite mixture presented a significant $\mathrm{AEF}(\mathrm{p}<0.05)$, resulting in increases in the yield of long and total stems, fresh and dry matter, and extracted N (Table 1). For total stems, the application of $60 \mathrm{~kg} \mathrm{ha}^{-1} \mathrm{~N}$ with zeolite presented a AEF superior $(\mathrm{p}<0.05)$ to that reached by the rate of $60 \mathrm{~kg} \mathrm{ha}^{-1} \mathrm{~N}$ alone, which was 135.8 stems per kilogram of $\mathrm{N}$ applied. In this case, the used

Table 1. Agronomic efficiency of the urea and zeolite mixture applied at the rates of 60 and $120 \mathrm{~kg}^{-1} \mathrm{~N}$ to the rose $(R o s a$ spp.) crop in April and June.

\begin{tabular}{|c|c|c|c|c|c|c|c|}
\hline \multirow[t]{2}{*}{ Treatment $^{(1)}$} & \multicolumn{4}{|c|}{ Stem (units per kg) } & \multicolumn{2}{|c|}{ Yield $\left(\mathrm{kg} \mathrm{kg}^{-1}\right)$} & \multirow{2}{*}{$\begin{array}{c}\text { N extraction } \\
\left(\mathrm{g} \mathrm{kg}^{-1}\right)\end{array}$} \\
\hline & Short & Medium & Long & Total & Fresh matter & Dry matter & \\
\hline & \multicolumn{7}{|c|}{ April } \\
\hline U120AZ & $86.4^{*}$ & 111.1 & $12.3 *$ & $209.9 *$ & $4.3^{*}$ & $0.6^{*}$ & $19.3^{*}$ \\
\hline U120 & -6.2 & 43.2 & -92.6 & -55.6 & -0.1 & -0.9 & -18.6 \\
\hline U60AZ & 61.7 & 197.5 & $222.2 *$ & $481.5^{*}$ & $12.8^{*}$ & $2.9^{*}$ & $56.0^{*}$ \\
\hline \multirow[t]{2}{*}{ U60 } & 0.0 & 61.7 & -49.4 & 12.3 & 0.6 & -0.5 & -11.9 \\
\hline & \multicolumn{7}{|c|}{ June } \\
\hline U120AZ & 55.6 & 12.3 & 18.5 & 86.4 & 1.9 & 0.4 & 16.4 \\
\hline U120 & 43.2 & 6.2 & 0.0 & 49.4 & 1.0 & 0.15 & 6.2 \\
\hline U60AZ & 37.0 & 49.4 & $135.8^{*}$ & $222.2 *$ & $6.3^{*}$ & $2.9^{*}$ & $76.2^{*}$ \\
\hline U60 & 0.0 & -12.3 & -123.5 & -135.8 & -6.0 & -2.1 & -53.9 \\
\hline
\end{tabular}

(1)U120AZ, $120 \mathrm{~kg} \mathrm{ha}^{-1} \mathrm{~N}$ and zeolite; U120, $120 \mathrm{~kg} \mathrm{ha}^{-1} \mathrm{~N}$ alone; U60AZ, $60 \mathrm{~kg} \mathrm{ha}^{-1} \mathrm{~N}$ and zeolite; and U60, $60 \mathrm{~kg} \mathrm{ha}^{-1} \mathrm{~N}$ alone. *Significant by Student's t-test, at $\mathrm{p}<0.05$. 
mixture resulted in an increment of approximately 30 dozen stems per kilogram of $\mathrm{N}$.

The possible saturation of the soil sorption complex due to the high $\mathrm{N}$ input of $120 \mathrm{~kg} \mathrm{ha}^{-1}$ may have led to the absence of significant differences $(\mathrm{p}>0.05)$ among the AEF for all variables in $\mathrm{C} 2$ when this rate and zeolite were applied, as well as to a higher AEF for the mixture of zeolite and $60 \mathrm{~kg} \mathrm{ha}^{-1} \mathrm{~N}(\mathrm{p}<0.05)$, compared with that with $120 \mathrm{~kg} \mathrm{ha}^{-1} \mathrm{~N}$ in $\mathrm{C} 1$ (Table 1). In this case, the hypothesis of the effect of the high concentration of $\mathrm{NH}_{4}^{+}$on the absorption of the other cations, especially of $\mathrm{K}^{+}$, must be taken into account. Furthermore, the formula to determine the AEF (Dobermann, 2007) uses the $\mathrm{N}$ rate $\left(\mathrm{kg} \mathrm{ha}^{-1}\right)$ as a dividend, expanding the difference among the AEF obtained by the treatments with zeolite and 60 and $120 \mathrm{~kg} \mathrm{ha}^{-1} \mathrm{~N}$.

The significant AEF $(\mathrm{p}<0.05)$ for total stem yield, reached by the mixture of $60 \mathrm{~kg} \mathrm{ha}^{-1} \mathrm{~N}$ with zeolite in $\mathrm{C} 1$ and $\mathrm{C} 2$, can be attributed to the yield of long stems, which was of 222.2 and 135.8 units per kilogram of $\mathrm{N}$ applied, respectively (Table 1 ). This shows that the urea and zeolite mixture increases the quantitative yield of commercial stems, as well as their quality.

The AEFs for fresh and dry matter yield and $\mathrm{N}$ extraction - with both rates of the zeolite mixture in $\mathrm{C} 1$ and only with the lowest rate in $\mathrm{C} 2$ - were higher $(p<0.05)$ than that obtained for the same variables but using single urea (Table 1). The increments on fresh and dry matter yield and $\mathrm{N}$ extraction due to the urea and zeolite mixture result in a greater vegetative growth of the rose bush stems and increase total stem yield.

The efficacy of the fertilizers, in general, is determined by soil and climate factors, the adopted agronomic practices, the efficiency of the used crop, and the characteristics of the applied fertilizer (Pan et al., 2016). In the last decades, good agronomic practices and plant genetic improvement were the main production factors in the agenda of technological development, effectively contributing to an increase in agricultural yield (Embrapa, 2018). However, the technical development of fertilizers was not equivalent to that of the other production factors.

The AEF specifically derives from the capacity of a plant (genotype) of using the applied nutrients and from the adopted management practices (Dobermann, 2007). In the present work, the rose bush plants were of the same genotype, and crop management was identical throughout the experimental area, except regarding $\mathrm{N}$ fertilization. Therefore, it can be concluded that the significant AEF $(\mathrm{p}<0.05)$ obtained by 60 and $120 \mathrm{~kg} \mathrm{ha}^{-1} \mathrm{~N}$ with zeolite in $\mathrm{C} 1$ and by $60 \mathrm{~kg} \mathrm{ha}^{-1} \mathrm{~N}$ with zeolite in $\mathrm{C} 2$ (Table 1) is due to the effects of the urea and zeolite mixture, showing that the addition of the mineral modified $\mathrm{N}$ dynamics in the soil-plantatmosphere system, as reported by Ramesh \& Reddy (2011), Werneck et al. (2012), Bernardi et al. (2013a, 2013b, 2016), and Latifah et al. (2017).

The obtained results are indicative that zeolite can increase $\mathrm{N}$ use efficiency, especially in summer, by controlling the retention of $\mathrm{NH}_{4}^{+}$, a product from the hydrolysis of urea in the soil, since the principle of action of zeolite is the reduction of $\mathrm{NH}_{4}{ }^{+}$concentration in the soil solution by cationic exchange (Ferguson \& Pepper, 1987; Latifah et al., 2017). Ramesh \& Reddy (2011), Bernardi et al. (2013a, 2013b), and Campana et al. (2015) also observed beneficial effects of the use of zeolite together with urea.

The mixture of urea and zeolite showed a productive and quality advantage compared with single urea. These results suggest that zeolite application could be a valuable tool to reduce $\mathrm{N}-\mathrm{NH}_{3}$ volatilization losses by retaining the applied $\mathrm{N}$ in ammoniacal form. Therefore, that mineral, as a fertilizer amendment, has potential to ameliorate the negative $\mathrm{N}$ fertilization impact on the agrosystem of rose bushes and to contribute to the innovative technology of new fertilizer formulations.

Further research should focus on developing new technologies for fertilizers and on assessing the environmental impacts of new products. Moreover, since, in the present study, only two rates of urea and two fertilization times were evaluated, future studies will be necessary to cover other fertilization rates and times to represent the entire fertilization program of the rose crop.

\section{Conclusions}

1. The mixture of zeolite with urea reduces the losses of $\mathrm{N}_{-} \mathrm{NH}_{3}$ by volatilization in the rose (Rosa spp.) crop.

2. The zeolite and urea mixture increases the agronomic efficiency of urea-N in the rose crop.

\section{Acknowledgments}

To Coordenação de Aperfeiçoamento de Pessoal de Nível Superior (Capes), for financing, in part, this study (Finance Code 001); and to Conselho Nacional de Desenvolvimento Científico e Tecnológico (CNPq), 
to Programa de Pós-Graduação em Agronomia Ciência do Solo (CPGA-CS) of Universidade Federal Rural do Rio de Janeiro (UFRRJ), to Centro de Tecnologias Minerais (Cetem), to Serviço Geológico do Brasil (CPRM), to Secretaria de Agricultura de Nova Friburgo, to Mr. Dorvalino Bernardo da Silveira and family, and to Financiadora de Estudos e Projetos (Finep) - Empresa Brasileira de Pesquisa Agropecuária (Embrapa) / Rede Brasil de Tecnologias (RBT), for financial support.

\section{References}

ARAÚJO, E. da S.; MARSOLA, T.; MIYAZAWA, M.; SOARES, L.H. de B.; URQUIAGA, S.; BODDEY, R.M.; ALVES, B.J.R. Calibração de câmara semiaberta estática para quantificação de amônia volatilizada do solo. Pesquisa Agropecuária Brasileira, v.44, p.769-776, 2009. DOI: https://doi.org/10.1590/S0100204X2009000700018.

BAPTISTA-FILHO, M.; SILVA, M.G. da; POLIDORO, J.C.; LUNA, F.J.; MONTE, M.B.M.; MIKLÓS, A.; SOUZA-BARROS, F.; VARGAS, H. Detection of ammonia released from zeolite by the quantum cascade laser based photoacoustic set-up. The European Physical Journal Special Topics, v.153, p.547-550, 2008. DOI: https://doi.org/10.1140/epjst/e2008-00505-6.

BARBOSA, J.G. Produção comercial de rosas. Viçosa: Aprenda Fácil, 2003. 200p.

BERNARDI, A.C. de C.; OLIVIERA, P.P.A.; MONTE, M.B. de M.; SOUZA-BARROS, F. Brazilian sedimentary zeolite use in agriculture. Microporous and Mesoporous Materials, v.167, p.1621, 2013a. DOI: https://doi.org/10.1016/j.micromeso.2012.06.051.

BERNARDI, A.C. de C.; SOUZA, G.B. de; POLIDORO, J.C.; PAIVA, P.R.P.; MONTE, M.B. de M. Yield, quality components, and nitrogen levels of silage corn fertilized with urea and zeolite. Communications in Soil Science and Plant Analysis, v.42, p.1266-1275, 2011. DOI: https://doi.org/10.1080/00103624.2011.5 71980.

BERNARDI, A.C.C.; MOTA, E.P.; CARDOSA, R.D.; MONTE, M.B.M.; OLIVEIRA, P.P.A. Ammonia volatilization from soil, dry matter yield, and nitrogen levels of Italian ryegrass. Communications in Soil Science and Plant Analysis, v.45, p.153-162, 2013b. DOI: https://doi.org/10.1080/00103624.2013.85 4804.

BERNARDI, A.C. de C.; POLIDORO, J.C.; MONTE, M.B. de M.; PEREIRA, E.I.; OLIVEIRA, C.R. de; RAMESH, K. Enhancing nutrient use efficiency using zeolites minerals: a review. Advances in Chemical Engineering and Science, v.6, p.295-304, 2016. DOI: https://doi.org/10.4236/aces.2016.64030.

CALDERANO FILHO, B.; PALMIERI, F.; GUERRA, A.J.T.; CALDERANO, S.B.; FIDALGO, E.C.C.; PRADO, R.B.; SILVA, E.F. da; CAPECHE, C.L.; FONSECA, O.O.M. da. Levantamento de solos e avaliação da aptidão agrícola das terras da microbacia Janela das Andorinhas no Município de Nova Friburgo, RJ. Rio de Janeiro: Embrapa Solos, 2003. 51p. (Embrapa Solos. Boletim de pesquisa e desenvolvimento, 27).
CAMPANA, M.; ALVES, A.C.; OLIVEIRA, P.P.A.; BERNARDI, A.C. de C.; SANTOS, E.A.; HERLING, V.R.; MORAIS, J.P.G. de; BARIONI JÚNIOR, W. Ammonia volatilization from exposed soil and Tanzania-grass pasture fertilized with urea and zeolite mixture. Communications in Soil Science and Plant Analysis, v.46, p.1024-1033, 2015. DOI: https://doi.org/10.1080/00103624.2 015.1019080 .

CARMO, C.A.F. de S. do; ARAÚJO, W.S. de; BERNARDI, A.C. de C.; SALDANHA, M.F.C. Métodos de análise de tecidos vegetais utilizados na Embrapa Solos. Rio de Janeiro: Embrapa Solos, 2000. 41p. (Embrapa Solos. Circular técnica, 6).

DOBERMANN, A. Nutrient use efficiency: measurement and management. In: IFA INTERNATIONAL WORKSHOP ON FERTILIZER BEST MANAGEMENT PRACTICES, 2007, Brussels. Fertilizer best management practices: general principles, strategy for their adoption and voluntary initiatives vs regulations: papers. Paris: International Fertilizer Industry Association, 2007. p.1-28.

EMBRAPA. Visão 2030: o futuro da agricultura brasileira. Brasília, 2018. 212p.

FERGUNSON, G.; PEPPER, I.L. Ammonium retention in sand amended with clinoptilolite. Soil Science Society of American Journal, v.51, p.231-234, 1987. DOI: https://doi.org/10.2136/ sssaj1987.03615995005100010047x.

IBRAFLOR. Instituto Brasileiro de Floricultura. Mercado de flores no Brasil. Available at: <https://www.ibraflor.com.br/ numeros-setor>. Accessed on: Mar. 312021.

IFA. International Fertilizer Association. IFASTAT: Consumption. 2018. Available at: <https://www.ifastat.org/ databases/plant-nutrition>. Accessed on: Mar. 312021.

LATIFAH, O.; AHMED, O.H.; MAJID, N.M.A. Enhancing nitrogen availability from urea using clinoptilolite zeolite. Geoderma, v.306, p.152-159, 2017. DOI: https://doi.org/10.1016/j. geoderma.2017.07.012.

MONTE, M.B.M.; MIDDEA, A.; PAIVA, P.R.P.; BERNARDI, A.C.C.; REZENDE, N.G.A.M.; BAPTISTA-FILHO, M.; SILVA, M.G.; VARGAS, H.; AMORIM, H.S.; SOUZA-BARROS, F. de. Nutrient release by a Brazilian sedimentary zeolite. Anais da Academia Brasileira de Ciências, v.81, p.641-653, 2009. DOI: https://doi.org/10.1590/S0001-37652009000400003.

NEVES, M.F.; PINTO, M.J.A. (Coord.). Mapeamento e quantificação da cadeia de flores e plantas ornamentais do Brasil. São Paulo: OCESP, 2015. 122p.

PAN, B.; LAM, S.K.; MOSIER, A.; LUO, Y.; CHEN, D. Ammonia volatilization from synthetic fertilizers and its mitigation strategies: a global synthesis. Agriculture, Ecosystems \& Environment, v.232, p.283-289, 2016. DOI: https://doi.org/10.1016/j.agee.2016.08.019.

RAMESH, K.; REDDY, D.D. Zeolites and their potential uses in agriculture. Advances in Agronomy, v.113, p.215-241, 2011. DOI: https://doi.org/10.1016/B978-0-12-386473-4.00004-X.

REIS, J.L.C. da S.; MARAFON, G.J. A dimensão espacial da rede de flores e plantas ornamentais do estado do Rio de Janeiro: uma análise a partir do município de Nova Friburgo, entre os anos de 2002 e 2018. Geo UERJ, n.36, e47278, 2020. DOI: https://doi.org/10.12957/geouerj.2020.47278. 
REZENDE, N.G.A.M.; ANGELICA, R.S. Sedimentary zeolites in Brazil. Mineralogica et Petrographica Acta, v.42, p.71-82, 1999.

RIBEIRO, A.C.; GUIMARÃES, P.T.G.; ALVAREZ V., V.H.(Ed.). Recomendações para o uso de corretivos e fertilizantes em Minas Gerais: $5^{\mathrm{a}}$ aproximação. Viçosa: Comissão de Fertilidade do Solo do Estado de Minas Gerais, 1999. 359p.

TIMILSENA, Y.P.; ADHIKARI, R.; CASEY, P.; MUSTER, T.; GILL, H.; ADHIKARI, B. Enhanced efficiency fertilisers: a review of formulation and nutrient release patterns. Journal of the Science of Food and Agriculture, v.95, p.1131-1142, 2015. DOI: https://doi.org/10.1002/jsfa.6812.
VILLAS BÔAS, R.L.; GODOY, L.J.G. de; BACKES, C.; LIMA, C.P. de; FERNANDES, D.M. Exportação de nutrientes e qualidade de cultivares de rosas em campo e em ambiente protegido. Horticultura Brasileira, v.26, p.515-519, 2008. DOI: https://doi.org/10.1590/S0102-05362008000400018.

WERNECK, C.G.; BREDA, F.A.; ZONTA, E.; LIMA, E.; POLIDORO, J.C.; BALIEIRO, F. de C.; BERNARDI, A.C. de C. Volatilização de amônia proveniente de ureia com zeólita natural. Pesquisa Agropecuária Brasileira, v.47, p.466-470, 2012. DOI: https://doi.org/10.1590/S0100-204X2012000300020. 